\title{
Studies on the Development of Potential Biomarkers for Rapid Assessment of Copper Toxicity to Freshwater Fish using Esomus danricus as Model
}

\author{
S. S. Vutukuru ${ }^{1}$, Ch.Suma ${ }^{1}$, K. Radha Madhavi ${ }^{1}$, Juveria ${ }^{1}$, J. Smitha Pauleena ${ }^{1}$, J. Venkateswara Rao ${ }^{2}$ and Y. $^{2}$ \\ Anjaneyulu ${ }^{1 *}$ \\ ${ }^{1}$ Environmental and Molecular Toxicology Laboratory, Centre for Environment, Institute of Science and Technology, \\ Jawaharlal Nehru Technological University, Kukatpally, Hyderabad - 500 072, Andhra Pradesh, India \\ ${ }^{2}$ Scientist E-II, Toxicology Unit, Biology Division, Indian Institute of Chemical Technology, Hyderabad 500 007, India \\ ${ }^{3}$ Director, Institute of Science and Technology, Jawaharlal Nehru Technological University, Kukatpally, Hyderabad-500 \\ 072, Andhra Pradesh, India \\ *Correspondence to Prof. Y. Anjaneyulu. Email: myvutukuru@yahoo.com
}

Received: 15 November 2004 / Accepted: 06 February 2005 / Published: 30 April 2005

\begin{abstract}
Living in an environment that has been altered considerably by anthropogenic activities, fish are often exposed to a multitude of stressors including heavy metals. Copper ions are quite toxic to fish when concentrations are increased in environmental exposures often resulting in physiological, histological, biochemical and enzymatic alterations in fish, which have a great potential to serve as biomarkers. Esomus danricus was chosen as model in the present study and the metabolic rate, gill morphology, total glycogen, total protein, superoxide dismutase and catalase were critically evaluated. The $96 \mathrm{~h} \mathrm{LC}_{50}$ value was found to be $5.5 \mathrm{mg} / \mathrm{L}(\mathrm{Cu}$ as $1.402 \mathrm{mg} / \mathrm{L})$. Fish groups were separately exposed to lethal $(5.5 \mathrm{mg} / \mathrm{L})$ and sub lethal concentrations $(0.55 \mathrm{mg} / \mathrm{L})$ of copper sulphate over a period of $96 \mathrm{~h}$ to examine the subtle effects caused at various functional levels. Controls were also maintained simultaneously. Significant decrease in the metabolic rate $(p<0.001)$ of the fish was observed in both the concentrations studied. Studies employing Automated Video Tracking System revealed gross changes in the architecture of gill morphology like loss, fusion, clubbing of secondary gill lamellae, and detachment of gill rakers following softening of gill shaft in fish under lethal exposures indicating reduced respiratory surface area. Biochemical profiles like total glycogen and total protein in gills and muscle of fish exposed to $5.5 \mathrm{mg} / \mathrm{L}$ showed appreciable decrease ( $p<0.05$ to 0.001$)$ from control. Significant inhibition of superoxide dismutase (60.83\%), catalase (71.57\%) from control was observed in fish exposed to $5.5 \mathrm{mg} / \mathrm{L}$ at the end of $96 \mathrm{~h}$ exposure only. Interestingly, in fish exposed to $0.55 \mathrm{mg} / \mathrm{L}$ enzyme activity is not affected except for catalase. Toxic responses evaluated at various functional levels are more pronounced in fish exposed to $5.5 \mathrm{mg} / \mathrm{L}$ and these can serve as potential biomarkers for rapid assessment of acute copper toxicity in environmental biomonitoring.
\end{abstract}

Keywords: Copper toxicity, Esomus danricus, biomarkers, Rapid assessment, Biomonitoring

\section{Introduction}

Environmental pollutants such as metals, pesticides and other organics pose serious risks to many aquatic organisms including fish [1]. Heavy metals constitute a core group of aquatic pollutants [2]. The crux of the problem lies in the fact that these metals not only accumulate in waters and sediments but also concentrate in the tissues of the fish causing alterations at various functional levels of the organism. Copper is one of 26 essential trace elements occurring naturally in plant and animal tissues and its availability is influenced by physico-chemical, hydrodynamic and biological factors. It makes its way into the receiving waters by extensive use in agriculture apart from usage in various industries like textile, tanneries, paints, battery, laundry, photography, copper ware and piping for water distribution systems. Copper ions are quite toxic to fish at various functional levels when environmental concentrations are increased [3]. 
Acute toxicity of a xenobiotic often can be very helpful in predicting and preventing acute damage to aquatic life in receiving waters as well as in regulating toxic waste discharges [4]. Gill architecture of fish is an important index in understanding the effect of heavy metals on the structural integrity of vital organs at cellular level. Respiratory distress is one of the earliest manifestations of heavy metal toxicity [5]. The toxic effects may result from the bioconcentration of metals and their consequent binding with biologically active constituents of the body such as lipids, amino acids, enzymes and proteins [6]. Despite the essential role of copper in a number of vital biochemical processes including cellular respiration, the metal has the potential to exert adverse toxicological effects [7]. The metal is known to impair glycolysis in freshwater fish [8]. Copper also acts as an enzyme activator as it is incorporated into enzymes like cytochrome oxidase, superoxide dismutase [9]. The activity of these enzymes is dependent on the adequate supply of metal but excess copper can also inhibit the activity of enzymes. Copper due to its redox potential generates free radicals leading to oxidative stress, which damages cellular components like lipids by causing lipid peroxidation, DNA and proteins if not quenched by the antioxidants. The occurrence of such alterations in biochemical profiles has a great potential to serve as 'biomarkers'.

Fish has a great potential to serve as sensitive indicators, signalling exposure and understanding the toxic mechanisms of stressors in aquatic ecosystems. Less frequently studied are the implications of interrelated toxic effects on the survival, histology, physiology, biochemical constituents and behaviour caused by aquatic pollutants for fish populations. To establish these effects a systematic evaluation was carried out on the above parameters in the present study using Esomus danricus exposed to lethal and sub-lethal concentrations of copper so that these responses can be employed as potential indicators of its toxicity in freshwaters.

\section{Materials and Methods}

\section{Collection of Fish and Maintenance}

Esomus danricus were collected from Undasagar fish

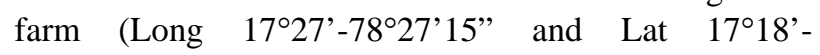
$\left.17^{\circ} 18^{\prime} 15^{\prime}\right)$ located nearby Hyderabad for toxicity tests. The fishes were transported from the farm in oxygenated polythene bags to the laboratory and immediately transferred into glass aquaria of $100 \mathrm{l}$ capacity containing well-aerated unchlorinated ground water. Fish were screened for pathological signs, if any and acclimated for a fortnight in the glass aquaria of $50 \mathrm{l}$ capacity before the experiments. Rice bran was fed to the fish ad libitum during the acclimation period. Healthy fish that showed active movements were only considered for the experimentation.

\section{Determination of Median Lethal Concentration (96h $\left.L C_{50}\right)$}

Prior to the acclimation of fish, the physico-chemical characteristics of the dilution water were analyzed adopting standard protocols [4] owing to their role in determining the toxic potential of heavy metals. Renewal bioassay was adopted in the present study due to its advantages over other bioassay techniques. This method has the advantage of replacing the toxicant solution afresh every $24 \mathrm{~h}$ so that metabolic waste (ammonia) which itself is highly toxic can be removed, sustains copper bioavailability besides replenishment of dissolved oxygen. Desired concentrations of copper were derived by adding aliquots of $1 \% \mathrm{CuSo}_{4} \cdot 5 \mathrm{H}_{2} \mathrm{O}$ stock solution (prepared in double distilled water) and the dilution water in the test chambers was renewed and fresh solution of same concentration was added every $24 \mathrm{~h}$. Pilot experiments were conducted to choose concentrations that resulted in mortality of the fish within the range of $5 \%$ to $95 \%$. Fish measuring from $4.6 \mathrm{~cm}$ with a weight of $1.45 \mathrm{~g}$ are used. The fish were starved $24 \mathrm{~h}$ prior to and also during the course of the experiment. Glass aquaria of $50 \mathrm{l}$ capacity were used as test chambers and 30 fish were tested in each concentration. The loading of fish in the test chambers was according to the recommendations [10]. No distinction was made between sexes.

Definitive tests were later conducted using four concentrations of copper sulphate i.e. $2.5 \mathrm{mg} / \mathrm{L}, 5.0 \mathrm{mg} / \mathrm{L}$, $7.5 \mathrm{mg} / \mathrm{L}$ and $10.0 \mathrm{mg} / \mathrm{L}$, which resulted in the mortality of the fish within the range of $5 \%$ to $95 \%$. Thirty fish were exposed to each concentration separately. Controls without toxicant were also run simultaneously. Behavioural manifestations and condition of the fishes were noted every $24 \mathrm{~h}$ up to $96 \mathrm{~h}$. Between the experiments, the chambers were carefully washed to eliminate residual metal adsorption to walls. The fish that failed to respond even to strong tactile stimuli were considered dead and removed immediately. The mortalility of fish was recorded for each concentration of the toxicant and the data was used to find the median lethal concentration $\left(\mathrm{LC}_{50}\right)$ adopting probit analysis and the corresponding results were generated with computerized program [11]. The regression equations were calculated by the method of least squares and $96 \mathrm{~h}$ $\mathrm{LC}_{50}$ value was derived from the equation.

\section{Histological Biomarkers}

Esomus danricus (length $4.6 \mathrm{~cm}$ and weight $1.45 \mathrm{gm}$ ) were exposed to $96 \mathrm{~h} \mathrm{LC}_{50}$ concentration of copper sulfate $(5.5 \mathrm{mg} / \mathrm{L})$ and sub lethal concentration of copper sulfate $(0.55 \mathrm{mg} / \mathrm{L})$ for $96 \mathrm{~h}$. At the end of exposure period the fishes that survived were sacrificed and dissected carefully to isolate gill III tissue. The gills of control and exposed fishes were placed in saline and rinsed for 3 to 4 times thoroughly. They were placed on a glass slide and observed under a microscope (Polyvar, Reichert-Jung light microscope) attached to Ethovisionversion 2.3 (Noldus Information Technology, Netherlands) through a CCD camera (Sony CCD IRIS, Model No: SSC-M370CE). Instantly, the digital photographs were stored in the computer system. The magnification of the snaps was calibrated with the aid of ocular and stage micrometers (ERMA, TOKYO, JAPAN). 


\section{Physiological Biomarkers}

\section{Metabolic Rate}

Fish $(n=30)$ were exposed both to $5.5 \mathrm{mg} / \mathrm{L} ; 0.55 \mathrm{mg} / \mathrm{L}$ and a range of concentrations of copper sulphate $(1.5 \mathrm{mg} / \mathrm{L}, 2.5 \mathrm{mg} / \mathrm{L}, 5.0 \mathrm{mg} / \mathrm{L}, 7.5 \mathrm{mg} / \mathrm{L}$ and $10 \mathrm{mg} / \mathrm{L})$ that were used to determine the median lethal concentration and examined for any change in the metabolic rate and ventilation frequency over a period of 96h. Controls without toxicant were also run simultaneously. The oxygen consumption of the fish was estimated by using a DO probe (Century, CD 501, India). In this method, oxygen probe containing an electrode is connected to the electronic meter, which displays the dissolved oxygen in the sample water at a specific temperature $\left(25^{\circ} \mathrm{C}\right)$. Respiratory measurements were carried out as per the method [12]. A BOD bottle (300 ml) chamber was used as respiratory chamber, which was filled with tap water. The initial DO of the water was measured by introducing the probe into the respiratory chamber without any airbubbles. Fish were introduced into the bottle taking care to avoid air bubbles. The bottles were stoppered airtight and kept aside, undisturbed for an hour. At the end of one hour, the final DO of the water was measured using the DO probe and the fish were replaced into their corresponding aquaria, after each interval of exposure. This process was repeated for $5.5 \mathrm{mg} / \mathrm{L}, 0.55 \mathrm{mg} / \mathrm{L}$ and a range of concentrations viz., $1.5 \mathrm{mg} / \mathrm{L}, 2.5 \mathrm{mg} / \mathrm{L}$, $5.0 \mathrm{mg} / \mathrm{L}, 7.5 \mathrm{mg} / \mathrm{L}$ and $10.0 \mathrm{mg} / \mathrm{L}$. The experiments were repeated thrice and the arithmetic mean was considered. After the experiment, the wet weights of the fish were taken to calculate the metabolic rate. The amount of oxygen consumed by the fish in $1 \mathrm{~h}$ was expressed as $\mathrm{mg}$ $\mathrm{O}_{2} / \mathrm{h}$ and the metabolic rate as $\mathrm{mg} \mathrm{O}_{2} / \mathrm{g} / \mathrm{h}$. The respiratory measurements were made in diffused daylight and the time of experiment was kept constant (11.00am to $3.00 \mathrm{pm})$ to avoid the effect of time of day on the respiration of the fish.

\section{Ventilation Frequency}

The numbers of ventilation movements (opercular beats) were counted per 1 minute in the BOD bottle during the respiratory measurements. Performing the experiment in the BOD bottle aided in simultaneous determination of both the oxygen consumed and the ventilation rate of that particular fish.

\section{Biochemical Biomarkers}

Thirty fish were exposed both to $5.5 \mathrm{mg} / \mathrm{L}$ and $0.55 \mathrm{mg} / \mathrm{L}$ concentrations of copper and examined for any change in the biochemical constituents over a period of $96 \mathrm{~h}$. Controls without the toxicant were also run simultaneously. The fishes were sacrificed at the end of every $24 \mathrm{~h}$, blotted dry and weighed to the nearest $\mathrm{mg}$. They were later dissected to isolate the gill and muscle tissues. The tissues were dried for $24 \mathrm{~h}$, at $50{ }^{0} \mathrm{C}$ to eliminate water. The dried tissues were weighed to the nearest mg. The tissues of control were also processed similarly for biochemical analysis. The important biochemical biomarkers viz., total glycogen and total protein were analyzed as per the universally accepted protocols [13-14], respectively. The data are subjected to Unpaired Student's ' $t$ ' test [15]. $\mathrm{P}<0.05$ was selected as the criterion for statistical significance.

\section{Enzyme Biomarkers}

In a separate set of experiments, fish $(n=30)$ were exposed to $5.5 \mathrm{mg} / \mathrm{L}$ and $0.55 \mathrm{mg} / \mathrm{L}$ for a period of $96 \mathrm{~h}$. At the end of 24 and $96 \mathrm{~h}$ of exposure viscera was isolated to carry out the enzyme assays. The viscera are immediately homogenized $(10 \% \mathrm{w} / \mathrm{v})$ in $0.1 \mathrm{Mphosphate}$ buffer (Ph 7.5) using Potter- Elvehjam Homogenizer fitted with a Teflon pestle. The homogenates were centrifuged at $10,000-\mathrm{x} g$ for 10 minutes. The resultant supernatant of viscera was used as the enzyme source for the estimation of enzymes (antioxidants). All the enzyme preparations were carried out at $4^{\circ} \mathrm{C}$.

SOD activity in the viscera was estimated at the end of 24 and 96h of exposure [16]. A typical run for all the in vivo experiments in 96 well plates consisted of $220 \mu \mathrm{l}$ of Pyrogallol $\left(\mathrm{C}_{6} \mathrm{H}_{6} \mathrm{O}_{2}\right)$ and $30 \mu \mathrm{l}$ of enzyme sample for each well. The colour that was developed was recorded continuously for 10 minutes in kinetic mode at $420 \mathrm{~nm}$ using a molecular device UV-spectrophotometer supported by soft max-pro-3 software. The percent change in SOD activity of exposed organisms was calculated based on the control values. SOD activity was calculated as O.D/min/mg protein.

Catalase activity in the viscera was estimated at the end of 24 and $96 \mathrm{~h}$ of exposure [17]. A typical run for all the in vivo experiments in 96 well plates consisted of 1.0ml Hydrogen peroxide $\left(\mathrm{H}_{2} \mathrm{O}_{2} 0.059 \mathrm{M}\right)$ in phosphate buffer, $1.95 \mathrm{ml}$ of distilled water and $50 \mu \mathrm{l}$ of enzyme for each well (extracted from control and $\mathrm{LC}_{50}$ exposed organisms). The decrease in absorbance was measured immediately at 240nm using kinetic mode against distilled water blank with 10 seconds intervals for 2 minutes in a molecular device UV- spectrophotometer supported by soft max-pro-3 software. The percent change in Catalase activity of exposed organisms was calculated based on the control values. CAT activity was calculated as $\mathrm{O} . \mathrm{D} / \mathrm{min} / \mathrm{mg}$ protein.

\section{Results and Discussion}

\section{Median Lethal Concentration}

The concentrations of $\mathrm{CuSo}_{4} \cdot 5 \mathrm{H}_{2} \mathrm{O}$ tested in the present study were $1.5 \mathrm{mg} / \mathrm{L}(\mathrm{Cu}$ as $0.382 \mathrm{mg} / \mathrm{L}), 2.5 \mathrm{mg} / \mathrm{L}$ $(\mathrm{Cu}$ as $0.637 \mathrm{mg} / \mathrm{L}, 5.0 \mathrm{mg} / \mathrm{L}(\mathrm{Cu}$ as $1.275 \mathrm{mg} / \mathrm{L})$, $7.5 \mathrm{mg} / \mathrm{L}(\mathrm{Cu}$ as $1.912 \mathrm{mg} / \mathrm{L})$ and $10.0 \mathrm{mg} / \mathrm{L}(\mathrm{Cu}$ as $2.549 \mathrm{mg} / \mathrm{L})$. The mortality in different concentrations ranged from $6.66 \%(2.5 \mathrm{mg} / \mathrm{l})$ to $93.33 \%(10.0 \mathrm{mg} / \mathrm{l})$ and is dependent on both time and concentration.

Table 1 shows the physico-chemical characteristics of water used for acclimation, control and experiment. The percentage mortality of Esomus danricus over 96h exposure at different concentrations of $\mathrm{CuSO}_{4} \cdot 5 \mathrm{H}_{2} \mathrm{O}$ and the regression equation of the expected Probit (Y) and log concentration (X), 96h $\mathrm{LC}_{50}$ value, 95\% confidence

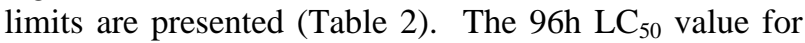
$\mathrm{CuSo}_{4} .5 \mathrm{H}_{2} \mathrm{O}$ is found to be $5.5 \mathrm{mg} / \mathrm{L}(\mathrm{Cu}$ as $1.402 \mathrm{mg} / \mathrm{L})$ 
and the $95 \%$ fiducial limits are $4.781 \mathrm{mg} / \mathrm{L}(\mathrm{Cu}$ as 1.219 $\mathrm{mg} / \mathrm{L})$ to $6.229 \mathrm{mg} / \mathrm{L}(\mathrm{Cu}$ as $1.588 \mathrm{mg} / \mathrm{L})$. The sub-lethal concentration $0.55 \mathrm{mg} / \mathrm{L} \quad(\mathrm{Cu}$ as $0.1402 \mathrm{mg} / \mathrm{L})$ was derived as $1 / 10^{\text {th }}$ of $\mathrm{LC}_{50}$ concentration.

Table 1: The physico-chemical characteristics of water used for acclimation, control and experiments

\begin{tabular}{ccc}
\hline S No & Parameter & Value \\
\hline 1. & $\mathrm{P}^{\mathrm{H}}$ & $7.0 \pm 0.5$ \\
2. & Temperature & $26.0{ }^{\circ} \mathrm{C}-27.0^{\circ} \mathrm{C}$ \\
3. & Dissolved oxygen & $6.0-8.0 \mathrm{mg} / \mathrm{L}$ \\
4. & Hardness & $220 \mathrm{mg} / \mathrm{L}$ \\
5. & Alkalinity & $432 \mathrm{mg} / \mathrm{L}$ \\
6. & Sulphates & $1.47 \mathrm{mg} / \mathrm{L}$ \\
7. & Chlorides & $95.74 \mathrm{mg} / \mathrm{L}$ \\
\hline
\end{tabular}

Table 2: Lethal Concentration $\left(\mathrm{LC}_{50}\right)$ of Copper to Esomus danricus

\begin{tabular}{ccc}
\hline $\begin{array}{c}\text { Regression } \\
\text { Equation } \\
Y=(\bar{y}-b \quad \bar{x})+b x\end{array}$ & $\begin{array}{c}\text { LC } C_{50} \text { of Copper } \\
\text { Sulphate }\end{array}$ & Fiducial Limits \\
& & \\
\hline & $5.5 \pm 0.369 \mathrm{mg} / \mathrm{L}$ & 4.781 to \\
$-7.621+4.60 \mathrm{X}$ & $(\mathrm{Cu}$ as $1.402 \pm 0.09)$ & $(\mathrm{Cu}$ as 1.219 to \\
& & $1.588)$. \\
\hline
\end{tabular}

The reaction and survival of aquatic animals depend on not only the biological state of the animals and physico-chemical characteristics of water but also on kind, toxicity, type and time of exposure to the toxicant [18]. In the present study, the mortality increased with an increase in the concentration of the toxicant and also the duration of exposure. This is in agreement with earlier studies explaining the relationship between exposure duration, tissue residues, growth and mortality in rainbow trout (Oncorhyncus mykiss) juveniles' subchronically exposed to copper [19]. Behavioural manifestations of acute toxicity like copious mucus secretion, loss of scales, grouping, loss of equilibrium was observed in Esomus danricus exposed to copper. Loss of swimming performance was also observed in brown trout, Salmo trutta exposed to sub lethal concentration of copper [20]. The effects of copper and zinc salts on Cyprinus carpio and Ctenopharyngodon idellus showed that the body and the gills of dead fish seemed to be covered by a veil-like film which looked like coagulated mucus and which was formed by the heavy-metal ions reacting with some constituents of the mucus secreted by the gill [21]. Heavy metal induced changes in physiology and survival of aquatic organisms is complicated because such changes differ from metal to metal, species to species and from one experimental condition to another which may also account for the differences in the $96 \mathrm{~h} \mathrm{LC}_{50}$ [22-23]. The exact causes of death due to heavy metal poisoning are multiple and depend mainly on time - concentration combinations.

\section{Gill Histology}

Figure 1 shows the histological structure of the normal gill characterized by the presence of primary lamellae along with secondary lamellae, shaft and rakers confirming the general architecture of the tissue. Gills exposed to $5.5 \mathrm{mg} / \mathrm{L}$ of copper have shown that the metal affected the primary and secondary lamellae, rakers and shaft. Figure 2 illustrates the degeneration of secondary gill lamellae with loss of original shape due to the onset of necrosis. Fish gills exposed to $0.55 \mathrm{mg} / \mathrm{L}$ shown that copper exposure produced hyper secretion of mucous (Figure 3).

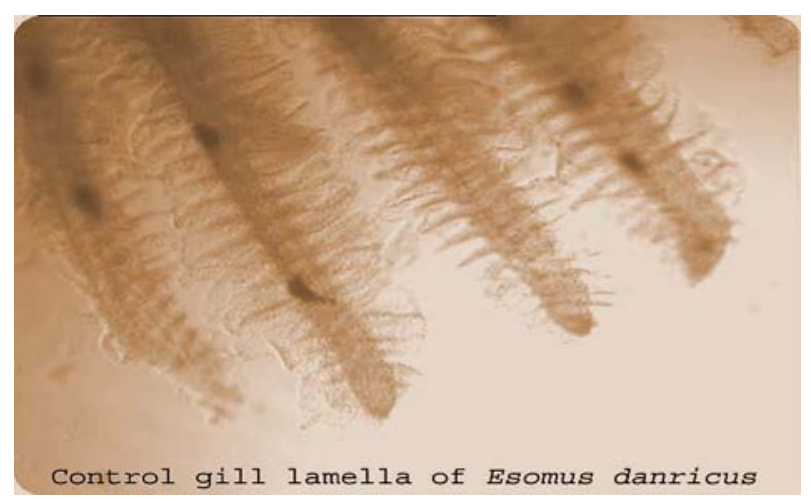

Figure 1 Control gill lamella of Esomus danricus

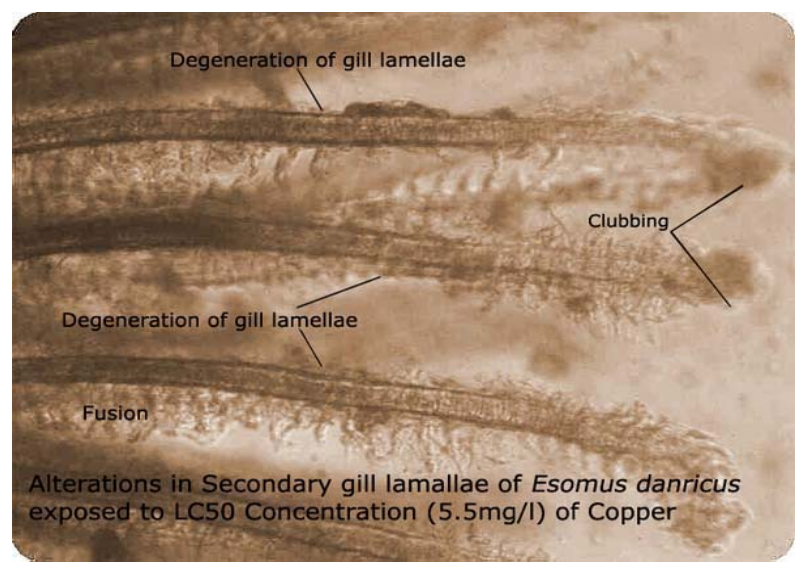

Figure 2 Alterations in secondary gill lamellae exposed to $5.5 \mathrm{mg} / \mathrm{l}$ of copper

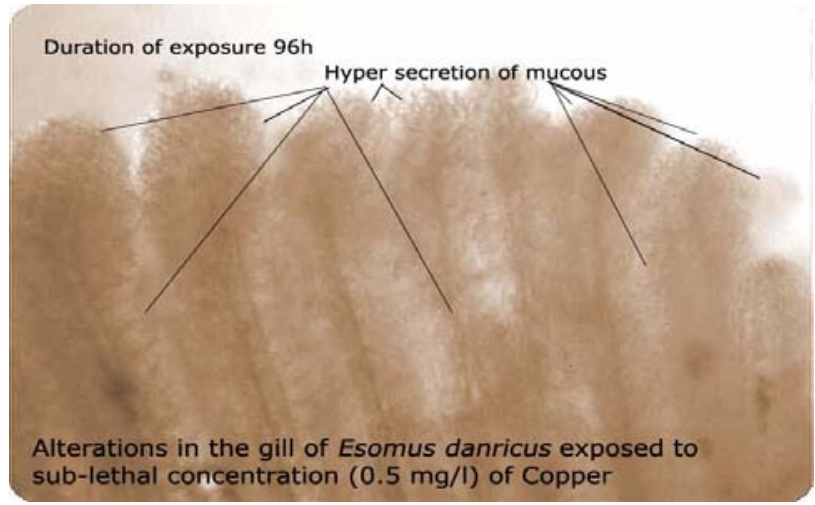

Figure 3 Alterations in gill of Esomus exposed to sublethal concentration $(0.55 \mathrm{mg} / \mathrm{L})$ ofcopper 
The fish gill has very little protection other than the body cover - the operculum- and is susceptible to both physical and chemical damage. A common response of the gill to irritation from any irritant is hyperplasia due to the chemical or physical irritation as a form of protection. Secondary lamellae clumped together affecting gaseous exchange and respiration. No gaseous exchange can take place and the fish literally suffocates. Since gills are the respiratory and osmoregulatory organs of the fish, cellular damage induced by the metal in terms of atrophy, bulging, hyperplasia of interlamellar epithelia, separation of epithelial layer might have probably impaired the respiratory function of the gill by reducing surface area. A thick coat of mucus covering entire gill filaments and lamellae was observed after 96h exposure to $\mathrm{LC}_{50}$ concentration of copper sulfate and the direct deleterious effect of the toxicant in the form of necrosis and abnormalities of gill lamellae is evident when compared to the control. The observed epithelial necrosis and rupture are direct responses induced by the action of copper sulfate.

Whether the changes in gill lamellae observed in the present study are secondary or primary effects of copper sulfate is difficult to establish, atrophy, bulging and desquamation of secondary gill lamellae can be due to the metal induced toxicity. A perusal of the available literature revealed that copper potentially damages the gill epithelium in a variety of fishes and it was indicated that the study of histology is a successful tool capable of revealing sensitively and selectively even the sub lethal effects of heavy metals on the environment and aquatic biota [24-28]. The changes in gill epithelia of Esomus danricus caused by copper may represent a defense response initially because these changes increase the distance across which copper must diffuse to reach the blood stream. They also increase the water-blood distance for oxygen diffusion whereas lamellar fusion reduces the respiratory area. Ironically, it was reported that the mucus layer on the gill surfaces creates a microenvironment, which may act as an ion trap, concentrating trace elements from the water [29]. Although Esomus has a reasonably large respiratory surface the changes observed in its gill tissue probably impaired branchial gas transfer, generating an internal hypoxia.

\section{Metabolic Rate}

Table 3 shows the effect of lethal and sub-lethal concentrations of copper sulphate on the metabolic rate of Esomus danricus. It is clear from the results that the metabolic rate decreased while the percentage decrease from control increased with an increase in the exposure period from 24 to $96 \mathrm{~h}$ to copper sulphate. The results of the ' $\mathrm{t}$ ' test show that the decrease in the metabolic rate is highly significant with $p<0.01$ and $p<0.001$ at the end of each exposure period.

The present investigation revealed a significant depression in the metabolic rate of Esomus danricus exposed to $\mathrm{CuSO}_{4} 5 \mathrm{H}_{2} \mathrm{O}$ with respect to time. With increase in time duration of the experiment, the metabolic rate in each concentration showed a decrease. At the end of $24 \mathrm{~h}, 48 \mathrm{~h}, 72 \mathrm{~h}$ and $96 \mathrm{~h}$, the metabolic rate showed significant decreases with increase in duration of exposure. Decrease in oxygen consumption is attributed to the onset of hypoxia and gill damage while the ventilation frequency increased to flush out the toxicant from the body. Reduced oxygen consumption can be attributed to increased mucous secretion, a specific property of copper to precipitate proteins and increase mucous secretion. As a result of gill damage, there is onset of acute hypoxia under metallic stress. The drop in the oxygen consumption also appears to be a protective mechanism to ensure that there is low intake of $\mathrm{CuSO}_{4}$. Architectural changes in the gills reduced their surface area, making it harder for the fish to extract oxygen from the water. Copper causes damage to gill tissues and induces fish mortality by the excessive cell proliferation and mucous production. Fish may asphyxiate due to excessive mucus [30]. Previous studies also reported that gills are vital respiratory and osmoregulatory organs and cellular damage induced by metals might impair the respiratory function of the fish by reducing the gill surface area [24-26, 31, 32].

Fish exposed to $5.5 \mathrm{mg} / \mathrm{L}$ and $0.55 \mathrm{mg} / \mathrm{L}$ of $\mathrm{CuSO}_{4}$, respectively, showed a decrease in metabolic rate as a function of time. But the metabolic rate of sub-lethal exposed fish showed lesser percentage decreases from the control than compared to that of the fish exposed to lethal concentration. This phenomenon can be accounted due to the fact that the sub-lethal concentration is very low and the stress induced is less when compared to that of the lethal concentration.

\section{Ventilation Frequency}

Table 4 shows the effect of lethal and sub-lethal concentrations of copper sulphate on the ventilation frequency of Esomus danricus in both the control and exposed fish at the end of 24h, 48h, 72h and 96h along with the percent increase from control. The ventilation rate and the percentage decrease from the control plotted against time is shown (Figure 4). The ventilation rate increased from control with an increase in the exposure period of 24h to $96 \mathrm{~h}$ to fish exposed to lethal, sub-lethal and lower concentrations of $1.5 \mathrm{mg} / \mathrm{L}, 2.5 \mathrm{mg} / \mathrm{L}$ and $5.0 \mathrm{mg} / \mathrm{L}$ of $\mathrm{CuSO}_{4}$. Interestingly, in higher concentrations of $7.5 \mathrm{mg} / \mathrm{L}$ and $10.0 \mathrm{mg} / \mathrm{L}$ there was an initial increase in the ventilation frequency up to $48 \mathrm{~h}$ and exhibited a significant drop at the end of 72 and $96 \mathrm{~h}$.

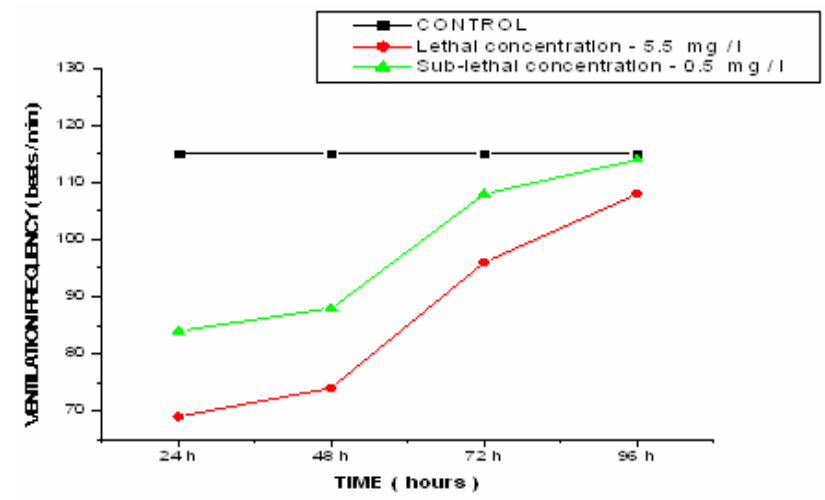

Figure 4: Effect of lethal and sub-lethal concentrations of copper on the ventilation frequency in Esomus 
Table 3: Effect of Lethal and Sub-lethal concentrations of copper sulphate on the metabolic rate (mg $\mathrm{O}_{2} / \mathrm{g} / \mathrm{h}$ ) Esomus danricus at the end of 24h, 48h, $72 \mathrm{~h}$ and $96 \mathrm{~h}$.

\begin{tabular}{|c|c|c|c|c|c|c|}
\hline \multirow{2}{*}{$\begin{array}{c}\text { Conc. of } \\
\mathrm{CuSO}_{4} 5 \mathrm{H}_{2} \mathrm{O}\end{array}$} & \multirow[b]{2}{*}{ Period of Exposure } & \multicolumn{2}{|c|}{$\begin{array}{c}\text { Metabolic Rate } \\
\mathrm{mg} \mathrm{O}_{2} / \mathrm{g} / \mathrm{h}\end{array}$} & \multirow{2}{*}{$\%$ Change } & \multirow{2}{*}{ ' $t$ ' value } & \multirow{2}{*}{ Result } \\
\hline & & $\begin{array}{r}\text { Control } \\
\bar{X} \pm S D \\
\end{array}$ & $\begin{array}{c}\text { Experiment } \\
\bar{X} \pm S D\end{array}$ & & & \\
\hline \multirow{4}{*}{$5.5 \mathrm{mg} / \mathrm{L}$} & $24 \mathrm{~h}$ & \multirow{4}{*}{$2.87 \pm 0.24$} & $2.46 \pm 0.08$ & -14.28 & 3.6155 & $P<0.01$ \\
\hline & $48 \mathrm{~h}$ & & $2.42 \pm 0.03$ & -15.67 & 4.2571 & $P<0.01$ \\
\hline & $72 \mathrm{~h}$ & & $2.04 \pm 0.12$ & -28.91 & 7.0452 & $P<0.001$ \\
\hline & $96 \mathrm{~h}$ & & $1.72 \pm 0.02$ & -40.07 & 10.9305 & $P<0.001$ \\
\hline \multirow{4}{*}{$0.55 \mathrm{mg} / \mathrm{L}$} & $24 \mathrm{~h}$ & \multirow{4}{*}{$2.87 \pm 0.24$} & $2.08 \pm 0.14$ & -2.44 & 0.5686 & $P>0.05$ \\
\hline & $48 \mathrm{~h}$ & & $2.76 \pm 0.22$ & -3.83 & 0.7607 & $P>0.05$ \\
\hline & $72 \mathrm{~h}$ & & $2.45 \pm 0.07$ & -14.63 & 3.8321 & $P<0.05$ \\
\hline & $96 \mathrm{~h}$ & & $2.16 \pm 0.05$ & -24.74 & 6.6003 & $P<0.001$ \\
\hline
\end{tabular}

Table 4: Effect of Lethal and Sub-lethal concentrations of copper sulphate on the ventilation frequency (beats/min) of Esomus danricus at the end of 24h, 48h, $72 \mathrm{~h}$ and $96 \mathrm{~h}$.

\begin{tabular}{|c|c|c|c|c|c|c|}
\hline \multirow{2}{*}{$\begin{array}{l}\text { Conc. Of } \\
\text { Copper }\end{array}$} & \multirow{2}{*}{ Period of Exposure } & \multicolumn{2}{|c|}{$\begin{array}{l}\text { Ventilation frequency } \\
\text { (beats/min) }\end{array}$} & \multirow{2}{*}{ \% Change } & \multirow{2}{*}{ 't' Value } & \multirow{2}{*}{ Result } \\
\hline & & $\begin{array}{r}\text { Control } \\
\bar{X} \pm S D \\
\end{array}$ & $\begin{array}{c}\text { Experiment } \\
\bar{X}+S D\end{array}$ & & & \\
\hline \multirow{4}{*}{$5.5 \mathrm{mg} / \mathrm{L}$} & $24 \mathrm{~h}$ & \multirow{4}{*}{$115 \pm 6.20$} & $69 \pm 10.25$ & -6.09 & 1.4768 & $P>0.05$ \\
\hline & $48 \mathrm{~h}$ & & $74 \pm 8.86$ & -16.52 & 2.9840 & $P<0.05$ \\
\hline & $72 \mathrm{~h}$ & & $96 \pm 12.83$ & -35.65 & 8.7674 & $P<0.001$ \\
\hline & $96 \mathrm{~h}$ & & $108 \pm 8.60$ & -40.00 & 8.5927 & $P<0.001$ \\
\hline \multirow{4}{*}{$0.55 \mathrm{mg} / \mathrm{L}$} & $24 \mathrm{~h}$ & \multirow{4}{*}{$115 \pm 6.20$} & $84 \pm 7.18$ & -0.87 & 0.1734 & $P>0.05$ \\
\hline & $48 \mathrm{~h}$ & & $88 \pm 9.03$ & -6.09 & 1.4152 & $P>0.05$ \\
\hline & $72 \mathrm{~h}$ & & $108 \pm 9.17$ & -23.48 & 5.5153 & $P<0.001$ \\
\hline & $96 \mathrm{~h}$ & & $114 \pm 11.64$ & -26.96 & 7.3120 & $P<0.001$ \\
\hline
\end{tabular}

As a result of gill damage, the oxygen consumption decreased which caused the fish more stress. In order to make more oxygen available from the water, the fish increase the rate at which they ventilate their gills [2728]. When fish pump water across their gills at a faster rate, more oxygen is available for uptake. Therefore, a link between the ventilation rate and oxygen consumption was observed. Because of gill damage, there was a decrease in oxygen consumption with an increase in ventilation frequency to overcome the metal induced stress. The increase in ventilation frequency can also be attributed to physiological stress induced by the toxicant. Because $\mathrm{CuSO}_{4}$ induces mucous secretion, a layer of thick mucous reduced the uptake of oxygen by covering the gills and as a result, the ventilation rate increased. The decrease in the ventilation frequency after an initial increase in the higher concentrations $(7.5 \mathrm{mg} / \mathrm{L}$ and $10 \mathrm{mg} / \mathrm{L}$ ) can be attributed to the fact that the stress induced in the fish due to the toxicant at the end of 96h exposure was so high that the fish could not tolerate any longer and perished. Decreased ventilation frequency in higher concentrations was due to the failure of the homeostatic mechanism to cope up with the increasing metal load (Figure 5)

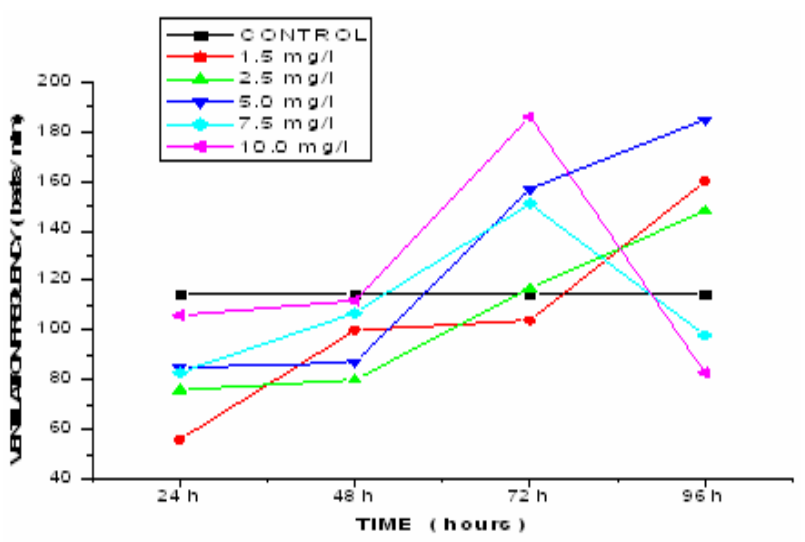

Figure 5: Effect of various concentrations of copper on Ventilation frequency in Esomus. 


\section{Biochemical Biomarkers}

The total glycogen and total protein contents expressed as mg per gram dry weight of the tissues, gills and muscle of Esomus danricus exposed to lethal and sub lethal concentrations of copper and control at the end of every 24h up to 96h are presented (Tables 5- 8).

Table 5: Total Glycogen content in gills of fish exposed to $5.5 \mathrm{mg} / \mathrm{L}$ and $0.5 \mathrm{mg} / \mathrm{L}$ of $\mathrm{CuSo}_{4} .5 \mathrm{H}_{2} \mathrm{O}$ and control at the end of every $24 \mathrm{~h}$ exposure and up to $96 \mathrm{~h}$.

\begin{tabular}{cccccc}
\hline $\begin{array}{c}\text { Concentration of the } \\
\text { Toxicant }(\mathrm{mg} / \mathrm{L})\end{array}$ & $\begin{array}{c}\text { Duration of } \\
\text { Exposure }(\mathrm{h})\end{array}$ & $\begin{array}{c}\text { Control } \bar{X} \pm S D \\
(\mathrm{mg} / \mathrm{g} \text { dry wt of Tissue) }\end{array}$ & $\begin{array}{c}\text { Experiment } \bar{X} \pm \text { SD } \\
(\mathrm{mg} / \mathrm{g} \text { dry wt of Tissue) }\end{array}$ & \% Change & Result \\
\hline \multirow{3}{*}{5.5} & 24 & $4.96 \pm 0.431$ & $4.57 \pm 0.289$ & -7.863 & $P>0.05$ \\
$(\mathrm{n}=5)$ & 48 & $4.96 \pm 0.431$ & $4.47 \pm 0.069$ & -9.879 & $P<0.05$ \\
& 72 & $4.96 \pm 0.431$ & $4.33 \pm 0.209$ & -12.702 & $P<0.01$ \\
& 96 & $4.96 \pm 0.431$ & $4.12 \pm 0.116$ & -16.935 & $P<0.01$ \\
\hline & 24 & $4.96 \pm 0.431$ & $4.78 \pm 0.173$ & -3.629 & $P>0.05$ \\
$(\mathrm{n}=5)$ & 48 & $4.96 \pm 0.431$ & $4.54 \pm 0.302$ & -8.467 & $P>0.05$ \\
& 72 & $4.96 \pm 0.431$ & $4.53 \pm 0.135$ & -8.669 & $P>0.05$ \\
& 96 & $4.96 \pm 0.431$ & $4.27 \pm 0.160$ & -13.911 & $P<0.01$ \\
\hline
\end{tabular}

Table 6: Total Glycogen content in muscle of fish exposed to $5.5 \mathrm{mg} / \mathrm{L}$ and $0.5 \mathrm{mg} / \mathrm{L}$ of $\mathrm{CuSo}_{4} .5 \mathrm{H}_{2} \mathrm{O}$ and control at the end of every 24h exposure and up to $96 \mathrm{~h}$.

\begin{tabular}{|c|c|c|c|c|c|c|}
\hline S No & $\begin{array}{l}\text { Concentration of } \\
\text { Toxicant }(\mathrm{mg} / \mathrm{L})\end{array}$ & $\begin{array}{l}\text { Duration of } \\
\text { Exposure (h) }\end{array}$ & $\begin{array}{c}\text { Control } \bar{X} \pm S D \\
\text { (mg/g dry wt of Tissue) }\end{array}$ & $\begin{array}{l}\text { Experiment } \bar{X} \pm S D \\
\text { (mg/g dry wt of tissue) }\end{array}$ & \% Change & Result \\
\hline 1. & \multirow{4}{*}{$\begin{array}{c}5.5 \\
(n=5)\end{array}$} & 24 & $11.75 \pm 0.554$ & $11.49 \pm 0.195$ & -2.213 & $P>0.05$ \\
\hline 2. & & 48 & $11.75 \pm 0.554$ & $11.46 \pm 0.358$ & -2.468 & $P>0.05$ \\
\hline 3. & & 72 & $11.75 \pm 0.554$ & $10.90 \pm 0.272$ & -7.234 & $P<0.01$ \\
\hline 4 & & 96 & $11.75 \pm 0.554$ & $10.82 \pm 0.208$ & -7.915 & $P<0.01$ \\
\hline 5. & \multirow{4}{*}{$\begin{array}{c}0.55 \\
(\mathrm{n}=5)\end{array}$} & 24 & $11.75 \pm 0.554$ & $11.70 \pm 0.212$ & -0.425 & $P>0.05$ \\
\hline 6. & & 48 & $11.75 \pm 0.554$ & $11.59 \pm 0.435$ & -1.362 & $P>0.05$ \\
\hline 7. & & 72 & $11.75 \pm 0.554$ & $11.54 \pm 0.261$ & -1.787 & $P>0.05$ \\
\hline 8 & & 96 & $11.75 \pm 0.554$ & $11.38 \pm 0.173$ & -3.149 & $P>0.05$ \\
\hline
\end{tabular}

Table 7: Total Protein content in gills of fish exposed to $5.5 \mathrm{mg} / \mathrm{L}$ and $0.5 \mathrm{mg} / \mathrm{L}$ of $\mathrm{CuSo}_{4} .5 \mathrm{H}_{2} \mathrm{O}$ and control at the end of every $24 \mathrm{~h}$ exposure and up to $96 \mathrm{~h}$.

\begin{tabular}{ccccccc}
\hline S No & $\begin{array}{c}\text { Concentration of } \\
\text { toxicant }(\mathrm{mg} / \mathrm{L})\end{array}$ & $\begin{array}{c}\text { Duration of } \\
\text { exposure }(\mathrm{h})\end{array}$ & $\begin{array}{c}\text { Control } \bar{X} \pm S D \\
(\mathrm{mg} / \mathrm{g} \text { dry wt of tissue })\end{array}$ & $\begin{array}{c}\text { Experiment } \bar{X} \pm S D \\
(\mathrm{mg} / \mathrm{g} \text { dry wt of tissue })\end{array}$ & \% Change & Result \\
\hline 1. & & 24 & $14.88 \pm 0.535$ & $13.75 \pm 1.662$ & -7.594 & $P>0.05$ \\
2. & 5.5 & 48 & $14.88 \pm 0.535$ & $12.30 \pm 0.964$ & -17.338 & $P<0.001$ \\
3. & $(\mathrm{n}=5)$ & 72 & $14.88 \pm 0.535$ & $11.76 \pm 0.513$ & -20.967 & $P<0.001$ \\
4. & & 96 & $14.88 \pm 0.535$ & $11.50 \pm 0.352$ & -22.715 & $P<0.001$ \\
\hline 5. & & 24 & $14.88 \pm 0.535$ & $14.75 \pm 0.172$ & -0.874 & $P>0.05$ \\
6. & 0.55 & 48 & $14.88 \pm 0.535$ & $14.50 \pm 0.467$ & -2.554 & $P>0.05$ \\
7. & $(\mathrm{n}=5)$ & 72 & $14.88 \pm 0.535$ & $13.75 \pm 1.66$ & -7.594 & $P>0.05$ \\
8. & & 96 & $14.88 \pm 0.535$ & $13.50 \pm 0.364$ & -9.274 & $P<0.01$ \\
\hline
\end{tabular}


Table 8: Total Protein content in muscle of fish exposed to $5.5 \mathrm{mg} / \mathrm{L}$ and $0.5 \mathrm{mg} / \mathrm{L}$ of $\mathrm{CuSo}_{4} .5 \mathrm{H}_{2} \mathrm{O}$ and control at the end of every 24h exposure and up to $96 \mathrm{~h}$.

\begin{tabular}{ccccccc}
\hline S No & $\begin{array}{c}\text { Concentration of } \\
\text { toxicant }(m g / L)\end{array}$ & $\begin{array}{c}\text { Duration of } \\
\text { Exposure (h) }\end{array}$ & $\begin{array}{c}\text { Control } \bar{X} \pm S D \\
(m g / g \text { dry wt of tissue) }\end{array}$ & $\begin{array}{c}\text { Experiment } \bar{X} \pm S D \text { dry wt of tissue) } \\
\text { (mg Change }\end{array}$ & Result \\
\hline 1. & & 24 & $23.5 \pm 1.893$ & $22.80 \pm 0.808$ & -2.979 & $P>0.05$ \\
2. & 5.5 & 48 & $23.5 \pm 1.893$ & $22.46 \pm 0.716$ & -4.426 & $P>0.05$ \\
3. & $(\mathrm{n}=5)$ & 72 & $23.5 \pm 1.893$ & $20.84 \pm 2.586$ & -11.319 & $P>0.05$ \\
4. & & 96 & $23.5 \pm 1.893$ & $20.12 \pm 2.059$ & -14.383 & $P<0.05$ \\
\hline 5. & & 24 & $23.5 \pm 1.893$ & $23.3 \pm 1.186$ & -0.851 & $P>0.05$ \\
6. & 0.55 & 48 & $23.5 \pm 1.893$ & $22.95 \pm 0.712$ & -2.340 & $P>0.05$ \\
7. & $(\mathrm{n}=5)$ & 72 & $23.5 \pm 1.893$ & $21.50 \pm 0.732$ & -8.511 & $P>0.05$ \\
8. & & 96 & $23.5 \pm 1.893$ & $21.39 \pm 0.853$ & -8.979 & $P>0.05$ \\
\hline
\end{tabular}

\section{Glycogen}

Gills

Table 5 shows the total glycogen content in gills of the fish exposed to lethal and sub lethal concentrations of copper. The total glycogen content in the gills of the fish exposed to lethal $(5.5 \mathrm{mg} / \mathrm{L})$ concentration was $4.57 \mathrm{mg}$, $4.47 \mathrm{mg}$, 4.33mg and $4.12 \mathrm{mg}$ and sub-lethal $(0.55 \mathrm{mg} / \mathrm{L})$ concentration was $4.78 \mathrm{mg}, 4.54 \mathrm{mg}, 4.53 \mathrm{mg}$ and 4.27 mg, showing a decrease of $7.863 \%, 9.879 \%, 12.702 \%$ and $16.935 \%$ in gills of fish exposed to $5.5 \mathrm{mg} / \mathrm{l}$ and $3.629 \%, 8.467 \%$, $8.669 \%$ and $13.911 \%$ in gills of fish exposed to $0.55 \mathrm{mg} / \mathrm{L}$ from control at the end of 24,48 , 72 and 96h, respectively. The 't' test values show that the decrease of glycogen content from control in gills of fish exposed to $5.5 \mathrm{mg} / \mathrm{L}$ is significant at the end of $48 \mathrm{~h}$ $(p<0.05) \quad 72 \mathrm{~h}$ and $96 \mathrm{~h} \quad(p<0.01)$ exposure periods whereas the decrease of the same in gills of fish exposed to $0.55 \mathrm{mg} / \mathrm{L}$ is significant only at the end of $96 \mathrm{~h}$ $(p<0.01)$.

\section{Muscle}

Decrease in total glycogen content was also observed in muscle of the fish exposed to lethal, sub lethal and other concentrations of copper. Table 6 shows that glycogen in muscle of fish exposed to $5.5 \mathrm{mg} / \mathrm{L}$ was $11.49 \mathrm{mg}, 11.46 \mathrm{mg}, 10.90 \mathrm{mg}$ and $10.82 \mathrm{mg}$ and that of the same in muscle of fish exposed to $0.55 \mathrm{mg} / \mathrm{L}$ was $11.70 \mathrm{mg}, 11.59 \mathrm{mg}, 11.54 \mathrm{mg}$ and $11.38 \mathrm{mg}$ at the end of every $24 \mathrm{~h}$ exposure and up to $96 \mathrm{~h}$ showing a decrease of $2.213 \%, 2.468 \%, 7.234 \%$ and $7.915 \%$ in $5.5 \mathrm{mg} / \mathrm{l}$ and $3.629 \%, 8.457 \%, 8.669 \%$ and $13.911 \%$ in $0.55 \mathrm{mg} / \mathrm{L}$ from control at the end of 24, 48, 72 and 96h, respectively. Statistical analysis show that the decrease in total glycogen content in muscle of fish exposed to 5.5 $\mathrm{mg} / \mathrm{L}$ is significant $(\mathrm{P}<0.01)$ at the end of $72 \mathrm{~h}$ and $96 \mathrm{~h}$ while the decrease of the same in muscle of fish exposed to $0.55 \mathrm{mg} / \mathrm{L}$ is insignificant.

\section{Total Protein}

Gills

The total protein content in gills of the fish exposed to lethal and sub lethal concentrations of copper are presented (Table 7). In gills of fish exposed to $5.5 \mathrm{mg} / \mathrm{L}$, the total protein content was $13.75 \mathrm{mg}, 12.30 \mathrm{mg}, 11.76$ $\mathrm{mg}$ and $11.50 \mathrm{mg}$ and that of gills of fish exposed to 0.55 $\mathrm{mg} / \mathrm{L}$ was $14.75 \mathrm{mg}, 14.50 \mathrm{mg}, 13.75 \mathrm{mg}$ and $13.50 \mathrm{mg}$ at the end of every $24 \mathrm{~h}$ exposure period and up to $96 \mathrm{~h}$. A decrease of $7.594 \%, 17.338 \%, 20.967 \%$ and $22.715 \%$ in $5.5 \mathrm{mg} / \mathrm{l}$ and $0.874 \%, 2.554 \%, 7.594 \%$ and $9.274 \%$ in $0.5 \mathrm{mg} / \mathrm{l}$ was observed from control at the end of 24,48 , 72 and $96 \mathrm{~h}$, respectively. The ' $\mathrm{t}$ ' test results show that the decrease in the gills of the fish exposed to $5.5 \mathrm{mg} / \mathrm{L}$ is significant $(p<0.01)$ at the end of 48,72 and $96 \mathrm{~h}$ while this decrease is significant only at the end of $96 \mathrm{~h}$ in gills of fish exposed to $0.55 \mathrm{mg} / \mathrm{L}$.

\section{Muscle}

Table 8 shows the protein content in muscle of fish exposed to $5.5 \mathrm{mg} / \mathrm{L}$ and $0.55 \mathrm{mg} / \mathrm{L}$ of copper. Protein content in muscle of fish exposed to $5.5 \mathrm{mg} / \mathrm{l}$ was 22.8 $\mathrm{mg}, 22.46 \mathrm{mg}, 20.84 \mathrm{mg}$ and $20.12 \mathrm{mg}$ and that of fish exposed to $0.55 \mathrm{mg} / \mathrm{L}$ was $23.3 \mathrm{mg}, 22.95 \mathrm{mg}, 21.50 \mathrm{mg}$ and $21.39 \mathrm{mg}$ at the end of 24, 48, 72 and 96h, respectively. A decrease of $2.979 \%, 4.426 \%, 11.319 \%$ and $14.383 \%$ in $5.5 \mathrm{mg} / \mathrm{l}$ and $0.8511 \%, 2.340 \%, 8.511 \%$ and $8.979 \%$ in $0.55 \mathrm{mg} / \mathrm{L}$ was observed at the end of 24 , 48, 72 and 96h, respectively. The results of the ' $\mathrm{t}$ ' test show that the decrease in total protein content in muscle of fish exposed to $5.5 \mathrm{mg} / \mathrm{L}$ is significant $(p<0.05)$ at the end of $96 \mathrm{~h}$ and that of fish exposed to $0.55 \mathrm{mg} / \mathrm{L}$ is insignificant.

It is evident that copper is highly toxic to the fish and the decrease in biochemical biomarkers viz., total glycogen and total protein content in gills and muscle of fish exposed $5.5 \mathrm{mg} / \mathrm{L}$ and $0.55 \mathrm{mg} / \mathrm{L}$ concentrations of copper demonstrated a linear and positive correlation 
with the concentration and duration of exposure indicating that the decrease in biochemical constituents is time and dose dependent.

Total glycogen content of Esomus danricus was depleted due to copper toxicity. Similar trends were also observed in other investigations on copper toxicity to freshwater fish. Copper was found to impair glycolysis in Labeo rohita [8]. A depletion of glycogen and phosphocreatine in the white muscle was observed in brown trout Salmo trutta exposed to sub-lethal concentration of copper in soft acidic water [20]. Decrease in glycogen level in liver of Oreochromis niloticus was reported with an increase in copper concentration in water [33]. The levels of carbohydrates and glycogen in aquatic organisms reveal their involvement in the endogenous derivation of energy during stress. Rapid depletion of muscle and liver glycogen reserves in order to compensate the energy needs of fish under acute metallic stress was also reported [39, 40]. A consistent decrease in the tissue glycogen reserves observed in this study suggests impaired glycogenesis. Further, the decline in the glycogen content might be partly due to its utilization in the formation of glycoproteins and glycolipids, which are essential constituents of various cell and other membranes. Decline in the glycogen content of the tissues of Esomus danricus may be due to its enhanced utilization since glycogen forms the immediate source of energy to meet the energy demands under metallic stress. It might be also due to the prevalence of hypoxic or anoxic conditions, which normally enhances glycogen utilization. Our studies revealed that copper triggers the onset of hypoxia in Esomus danricus. The enhanced utilization of glycogen and its consequent depletion in the tissues, therefore suggests the initiation of anaerobic glycolytic pathway by increased glycogenolysis as has been suggested [37].

There was also depletion in the total protein content in gills and muscle of Esomus danricus exposed to copper. Protein content can be taken as a biomarker of copper level. The decrease in the tissue proteins observed in the gills and muscle (Tables 5-8) could be partly due to their utilization in cell repair and tissue organization with the formation of lipoproteins, which are important cellular constituents, occurring in cell membranes and cell organelles present in cytoplasm. Direct utilization of proteins as immediate source of energy to meet the energy demands also cannot be ruled out [42]. The effects of metals may result from their binding with biological constituents of the body such as lipids, amino acids, enzymes and proteins [6]. The depletion in tissue proteins may be due to impaired or low rate of protein synthesis under metallic stress [43] or due to their utilization in the formation of mucoproteins, which are eliminated in the form of mucous. The depletion in protein may result in further modification of enzyme activity (stimulation or inhibition). Changes in protein content may also modify signal transfer in cells. Also attack on proteins can lead to the modification of amino acids, oxidation of sulphydryl groups, leading to conformational changes, cross linking, peptide bond cleavage as well as carbohydrate modification in glycoproteins. It can be substantiated that glycogen and protein contents under metallic stress in fish can be effectively employed as biomarkers for rapid assessment of heavy metal toxicity in bio monitoring of aquatic environments.

\section{Enzyme Biomarkers}

Table 9 illustrates the activity of superoxide dismutase and catalase in the viscera of the fish exposed to lethal and a sub lethal concentration of CuSO4.5H2O, respectively. The results show that there was significant decrease $(p<0.001)$ in the activity of superoxide dismutase in the viscera of the fish exposed to lethal and sub lethal concentrations of copper for 96h. There was significant $(p<0.001)$ decrease in the Catalase activity in viscera of the fish exposed to lethal and sub-lethal concentrations of $\mathrm{CuSO}_{4} .5 \mathrm{H}_{2} \mathrm{O}$ for both 24 and $96 \mathrm{~h}$. From the results it is evident that there is decrease in the antioxidant enzymes activity in the fish exposed to lethal and sub-lethal concentrations of $\mathrm{CuSO}_{4} \cdot 5 \mathrm{H}_{2} \mathrm{O}$.

Table 9: SOD and CAT activities in the viscera of fish exposed to $5.5 \mathrm{mg} / \mathrm{L}$ and $0.5 \mathrm{mg} / \mathrm{L}$ of $\mathrm{CuSo}_{4} .5 \mathrm{H}_{2} \mathrm{O}$ and control at the end of every $24 \mathrm{~h}$ exposure and $96 \mathrm{~h}$.

\begin{tabular}{|c|c|c|c|c|c|c|}
\hline $\begin{array}{c}\text { Concentration of } \\
\text { Toxicant }(\mathrm{mg} / \mathrm{L})\end{array}$ & $\begin{array}{l}\text { Duration of } \\
\text { Exposure (h) }\end{array}$ & Enzyme Assayed & $\begin{array}{c}\text { Control } \bar{X} \pm S D \\
\text { (mg/g dry wt of Tissue) }\end{array}$ & $\begin{array}{c}\text { Experiment } \bar{X} \pm S D \\
\text { (mg/g dry wt of Tissue) }\end{array}$ & \% Change & Result \\
\hline \multirow{4}{*}{$\begin{array}{c}5.5 \\
(n=5)\end{array}$} & 24 & SOD & $0.513 \pm 0.08$ & $0.48 \pm 0.03$ & -6.43 & $P>0.05$ \\
\hline & 24 & CAT & $2.44 \pm 0.10$ & $1.65 \pm 0.02$ & -32.78 & $P<0.05$ \\
\hline & 96 & SOD & $0.513 \pm 0.08$ & $0.201 \pm 0.02$ & -60.83 & $P<0.001$ \\
\hline & 96 & CAT & $2.44 \pm 0.10$ & $0.693 \pm 0.04$ & -71.57 & $P<0.001$ \\
\hline \multirow{4}{*}{$\begin{array}{l} \pm 0.55 \\
(\mathrm{n}=5)\end{array}$} & 24 & SOD & \pm 0.08 & $0.169 \pm 0.001$ & -3.42 & $P>0.05$ \\
\hline & 24 & CAT & \pm 0.08 & $0.281 \pm 0.008$ & -14.58 & $P<0.01$ \\
\hline & 96 & SOD & $0.175 \pm 0.08$ & $0.95 \pm 0.007$ & -45.37 & $P<0.001$ \\
\hline & 96 & CAT & $0.329 \pm 0.08$ & $0.125 \pm 0.010$ & -61.75 & $P<0.001$ \\
\hline
\end{tabular}


This decrease increased with duration of exposure and concentration of the metal. Appreciable decline in SOD activity in the viscera of silver fish, Esomus danricus was found under the impact of $\mathrm{Cu}$ toxicity when exposed to lethal and sub lethal concentrations for 96h. The decrease in the activity of the enzyme SOD could be due to its inhibition by excess production of ROS, decreased uptake in the diet, alteration in the gene expression or due to protein precipitation $[45,46]$.

Catalase activity declined significantly in the viscera of silver fish, Esomus danricus exposed to lethal and sub lethal concentrations for both 24 and 96h. The decrease in the Catalase activity could be due to its inactivation by Superoxide radical or due to decrease in the rate of reaction as a result of excess production of $\mathrm{H}_{2} \mathrm{O}_{2}$. Earlier reports attributed the inhibition of catalase activity due to Superoxide radical and demonstrated the synergism between the SOD and Catalase [47]. A decrease in the activity of catalase is due to excess free radical production by $\mathrm{Cu}$, which results in accumulation of $\mathrm{O}^{2-}$, and $\mathrm{H}_{2} \mathrm{O}_{2}$, which in addition to direct generation by $\mathrm{Cu}$ is also produced by dismutation of $\mathrm{O}^{2-}$ by superoxide dismutase. The $\mathrm{H}_{2} \mathrm{O}_{2}$ produced reacts with $\mathrm{O}^{2-}$ to form more reactive ROS like $\mathrm{OH}$, which damages the cellular components like DNA, proteins and lipids. Our studies also revealed a significant decrease in protein profiles of the fish, which substantiates the findings of the present study. A consistent decrease in the antioxidant enzyme levels was observed in the study suggesting that there is impaired antioxidant defense mechanism due to excess generation of oxy radicals by $\mathrm{Cu}$. Further, decline in antioxidant levels might also be due to overproduction of ROS which creates a net increase in the amount of oxygen free radicals present in the cell. Antioxidants like SOD act as primary preventive inhibitor by catalyzing the conversion of superoxide anion $\left(\mathrm{O}^{2-}\right)$ to $\mathrm{H}_{2} \mathrm{O}_{2}$ and $\mathrm{O}_{2}$ and scavenge the $\mathrm{O}_{2}$ produced by rapid dismutation reaction. Catalase functions to rapidly dismutase $\mathrm{H}_{2} \mathrm{O}_{2}$ to water and oxygen [48]. Therefore any significant reduction in these antioxidant levels results in lipid peroxidation, as normal levels of antioxidants produced could not quench the excess free radicals generated. The findings of the present study clearly demonstrated that enzymatic biomarkers like SOD and CAT in fish can be effectively used for rapid assessment of copper toxicity in biomonitoring of aquatic environment.

\section{Conclusions}

Copper is found to be highly toxic to Esomus danricus and induced gross alterations in the gill architecture, significant decrease in metabolic rate, biochemical constituents like glycogen and proteins and also key antioxidant enzymes superoxide dismutase and catalase suggesting that the metal exerts its effect at various functional levels of organization as a function of time with more pronounced changes occurring in the lethal exposures. These parameters could be effectively used as potential biomarkers of copper toxicity to the freshwater fish in the field of environmental biomonitoring.

\section{References}

1. Graham R. Scott.; Katherine A. Sloman: The effect of environmental pollutants on complex fish behaviour-integrating behavioural and physiological indicators of toxicity. Aquatic Toxicology, 2004, 68, 369-392.

2. Vutukuru, S. S.; Chromium induced alterations in some biochemical profiles of the Indian major carp, Labeo rohita (Hamilton). Bull.Environ. Contam. Toxicol. 2003, 70, 118-123.

3. Moore, J.W.; Ramamoorthy, S. Heavy metals in natural waters. Applied Monitoring and Impact Assessment,. Springer-Verlag, New York, 1984.

4. APHA; AWWA; WPCP: Standard methods for the examination of water and wastewater. $20^{\text {th }}$ ed. American Public Health Association, Washington, DC. 1998.

5. Sesha Srinivas, V.; Balaparameswara Rao, M.: Chromium induced alterations in the oxygen consumption of the freshwater fish, Labeo rohita (Hamilton). Poll Res. 1999, 18 (4), 377-380.

6. Passow, H.; Rothestein, A.; Clarkson, T. W.: The general pharmacology of heavy metals. Pharmacol.Rev, 1961, 13, 183-224.

7. Solomon, E. I.; Lowery, M. D.: Electronic structure contributions to function in bioinorganic chemistry. Science, 1993, 259, 1575 -1581.

8. Radhakrishnaiah, K.; Venkataramana, K.; Suresh, A.; Siva Ramakrishna, B. Effects of lethal and sublethal concentrations of copper on glycolysis in liver and muscle of freshwater teleost fish, Labeo rohita J. Environ. Biol, 1992, 13(1), 63-68.

9. U.S.E.P.A..; Health Issue Assessment: Copper p.3, EPA/600/8-97/001, 1987.

10. Methods for acute toxicity tests with fish, macro invertebrates and amphibians. U.S.E.P.A, E.R.S, EPA 660/3-75-009, 1975, 61 pp.

11. Finney, D. J.: Probit analysis $2^{\text {nd }}$ edition. Cambridge University press, Cambridge England, 1953.

12. Fitch, D. D.; Oxygen consumption in the Prosobranch snail, Viviparous contectoides (Mollusca: Gastropoda) Effects of weight and activity. Comp .Biochem. Physiol, 1975, 51A, 815-820.

13. Kemp Andienne, J. M.; Kits Van Hejningen.: A calorimetric micro method for the determination of glycogen. Biochem. J, 1954, 56, 640-648.

14. Lowry, O. H.; Rosebrough, N. J.; Lewis Farr, A.; Randall, R. J.: Protein measurement with Folin Phenol Reagent. J. Biol. Chem, 1951, 193, 265-275.

15. Bailey, N. T. J.: Statistical Methods in Biology. The English Language Book Society, Great Briton, 1959, 200pp.

16. Marklund. S.; Marklund. G.: Superoxide dismutase: Involvement of superoxide anion radical in auto oxidation of Pyrogallol and a convenient assay for superoxide dismutase. Eur J Biochem, 1974, 47, 469-474.

17. Beers. Jr, Ronald F.; Sizer, Irwin W.: Catalase: A spectrophotometer method for measuring the breakdown of hydrogen peroxide by catalase. $J$ Biol Chem, 1952, 195,133-140. 
18. Brungs, W. A.; McCormick, J. H.; Neiheisel, T. W.; Spehar, C. E.; Stokes, G. N.: Effects of pollution on freshwater fishes. J. W.P.C.F, Washington DC, 1977, 49, 1425-1493.

19. Hansen, J.A.; Lipton, J.; Welsh, P.G.; Morris, J.; Cacela, D.; Suedkamp, M.J. Relationship between exposure duration, tissue residues, growth, and mortality in rainbow trout (Oncorhyncus mykiss) juveniles sub-chronically exposed to copper. Aquat Toxicol, 2002, 58 (3-4), 175-88.

20. Beaumont, M. W.; Butler, P. J.; Taylor, E. W.: Exposure of brown trout, Salmo trutta, to a sublethal concentration of copper in soft acidic water: effects upon muscle metabolism and membrane potential. Aquat Toxicol, 2000, 51(2), 259-72.

21. Wong, M. H.; Luk, K. C.; Choi, K. Y.: The effects of zinc and copper salts on Cyprinus carpio and Ctenopharyngodon idellus. Acta Anat (Basel), 1977, 99(4), 450-54.

22. Alam, M. K.; Maughan, O. E.: The effect of Malathion, diazinon, and various concentrations of zinc, copper, nickel, lead, iron, and mercury on fish. Biol Trace Elem Res, 1992, 34(3), 225-236.

23. Vutukuru, Srinivas S.; Balaparameswara, Rao. M.: Impact of hexavalent chromium on survival of the freshwater fish, Sarotherodon mossambicus. J. Aqua. Biol, 2000, Vol. 15 (1 and 2), 71-73.

24. Mallat, J.: Fish gill structural changes induced by toxicants and other irritants: A statistical review. Can. J. Aquatic. Sci, 1985, 42, 189-206.

25. Sorensen, E. M. B.: Metal poisoning in fish. CRC Press, Inc., Boca Ranton, Florida, 1991, pp. 362.

26. Akhilender Naidu, K.; Abhinender Naidu, K.; Ramamoorthy, R.: Histological observations in gills of teleost fish, Sarotherodon mossambicus. Ecotoxicol and Environ Safety, 1983, 5, 455-462.

27. Sornaraj, R.; Baskaran, P.; Thanalakshmi, S.: Effects of heavy metals on some physiological responses of air breathing fish, Channa punctatus (Bloch). Environ.Ecol, 1995, 13(1), 202-207.

28. Rupa Mathew; Kanagaraj, M. K.; Manavalaramanujam, R.: Lead induced ventilation frequency, oxygen consumption and haemoglobin content in Cyprinus carpio. Poll Res, 1997, 16 (1), 51-53.

29. Lars Collivin: The effect of copper on maximum respiration rate and growth rate of perch, Perca fluvialtilis L. Water Res, 1984, 18, 139-144.

30. Borah Sabitha, S.; Yadav, R. N. S.: Static bioassay and toxicity of two pesticides, rogor and endosulfan to the air breathing fish, Heteropneustes fossilis, with special reference to behaviour. Poll. Res, 1995, 14 (4), 435-438.

31. Naigaga Irene. Bioaccumulation and histopathology of copper in Oreochromis mossambicus. M.Sc. (Ichthyology) Rhodes University Electronic Thesis Collection, 2003, TR 03-78.

32. James, R. K.; Sampath, K.; Punithavathi Ponmani, K.: Effect of metal mixtures on activity of two respiratory enzymes and their recovery in Oreochromis mossambicus (Peters). Ind. J. Exp. Biol, 1992, 30, 496-499.

33. Ali, A..; Al- Ogaily, S.; Al-Asgah, N. A..; Gropp, J.: Effect of sub lethal concentrations of copper on the growth performance of Oreochromis niloticus. Journal of Applied Ichthyology, 2003, 19, 4, 183.

34. Ram lingam, K.; Indra, D.: Copper Sulphate Toxicity on tissue phosphatases activity and carbohydrates turnover in Achatina fulica. $J$. Environ. Biol, 2002, 23(2), 181-188.

35. Natarajan, G. M.: Effect of zinc sulphate on the tissue glycogen content of air breathing climbing perch, Anabas scandens (Cuvier). Comp. Physiol.Ecol, 1982, 7, 37-39.

36. Gill Tejindra, S.; Tewari Hema.; Pande Jaishree. Short and long term effects of copper on the rosy barb (Puntius conchonius). Ecotoxicol Environ Safety, 1992, 23 (3), 294-306.

37. Dezwaan, A.; Zandee, D. I.: Body distribution and seasonal changes in glycogen content of the common sea mussel, Mytilus edulis. Comp Biochem Physiol, 1973, 43, 53-55.

38. Balavenkatasubbiah, M.; Usha Rani, A.; Geethanjali, K.; Purushottam, K. R.; Ramamoorthy, R.: Effect of cupric chloride on oxidative metabolism in the freshwater fish, Tilapia mossambica. Ecotoxicol and Environ Safety, 1984, 8(3), 289-291.

39. Johnston, I. A.: Studies on swimming musculature of rainbow trout Muscle metabolism during severe hypoxia. Jour. Fish. Biol, 1975, 7, 459.

40. Chandravathy, Mary; Reddy, S. L. N.: In vivo effects of lead acetate on dehydrogenase activities and metabolites in the freshwater fish, Anabas scandens. J. Ecotoxicol .Environ Monit, 1995, 5(2), 107-111.

41. Geetha, R.; Kumaragruru, A. K.; Thatheyus, A. J.: Toxic effects of Heavy metal Copper on the fish, Lepidocephalicthys thermalis in short term exposures. Poll. Res, 1996, 15 (2), 151-153.

42. Nagai, M.; Ikeda, S.: Carbohydrate metabolism in Fish-1. Effects of starvation and dietary composition on the blood glucose level and haepatopancreatic glycogen and lipid contents in Cyprinus carpio. Bull. Jap.Soc.Scient.Fish, 1971, 37, 404-409.

43. Syversen, T. L. M.: Effects of methyl mercury on protein synthesis in vitro. Acta. Pharmacol. Et.Toxicol, 1981, 49, 422-426.

44. Bellomo, G.; Mirabelli, F.; Richelmi, P.; Orrenius, S. S.: Critical role of sulphydryl group (s) in the ATP-dependent $\mathrm{Ca}^{+2}$ sequestration by the plasma membrane fraction from rat liver. FEBS Lett, 1983, 163, 136-139.

45. Stadtman, E. R.: Protein oxidation and aging. Science, 1992, 257, 1220-1224.46.

46. Helene Manduzio; Tiphaine Monsinjon; Beatrice Rocher; Franscois Leboulenger; Camille Galap: Characterization of inducible isoform of the $\mathrm{Cu} / \mathrm{Zn}$ superoxide dismutase in the blue mussel, Mytilus edulis. Aquatic toxicology, 2003, 64 (1), 73-83.

47. Kono, Y.; Fridovich, I.: Superoxide radical inhibits catalase. J Biol Chemistry, 1982, 257 (10), 5751-5754.

48. Kelly, Sue A.; Harvilla Christine, M.; Brady, Todd C.; Abramo, Kimberly Harris; Levin, Edward D.: Oxidative stress in toxicology: Established mammalian and emerging piscine model systems. Env. Hlth. Perspectives, 1998, 106(7), 375-383. 